ISSN 1119-7455

\title{
STUDIES ON INTRA AND INTER CORRELATIVE RESPONSES OF PHENOLOGICAL, YIELD AND POSTHARVEST TRAITS IN SOME PLANTAIN (MUSA SPP.) GENOTYPES IN NIGERIA
}

\author{
Ndukwe $^{1}$, O. O., Baiyeri ${ }^{2}$, K. P. Muoneke ${ }^{3}$, C. O. and Tenkouano, ${ }^{4}$ A.
}

${ }^{1}$ Department of Crop Science and Horticulture, Nnamdi Azikiwe University, Awka, Nigeria.

${ }^{2}$ Department of Crop Science, University of Nigeria, Nsukka, Nigeria.

${ }^{3}$ Department of Agronomy, Michael Okpara University of Agriculture, Umudike, Nigeria.

${ }^{4}$ Regional Centre for Africa, AVRDC - The World Vegetable Centre, Duluti, Arusha, Tanzania.

\begin{abstract}
The correlative responses of pre-flowering growth traits of Musa species with the corresponding growth parameters at flowering, components of yield, fruit shelf life and pulp nutrient concentrations were performed. Data were generated from two field experiments conducted for two cropping cycles (2006 - 2008) in Onne, the high rainfall station of the International Institute of Tropical Agriculture (IITA). Results revealed that the number of days to flowering and harvest were highly negatively correlated with the pre-flowering growth traits. Total leaf area per plant at 3 and 6 months after planting (MAP) correlated positively with the number of hands with r-values of $0.682 *$ and $0.661 *$, respectively. The correlation coefficients between the plant height and plant circumference at flowering and the number of hands were $0.969 * *$ and $0.982 * *$, respectively in 'PITA 14 '. Harvest index was strongly associated with the number of green leaves at flowering in 'PITA 14' $(r=0.952 *)$ and '30456-3' ( $r=0.780 *)$. The number of green leaves at flowering also had the strongest correlation with the index of non-spotted leaves $\left(r=0.957^{* *}\right)$ in 'PITA 14'. The concentration of phosphorus $(P)$ and potassium $(K)$ in the leaves at 3 MAP, however, had a positive association with the number of green leaves at flowering, fruit bulking period and the entire yield attributes. The leaf nitrogen (N) concentration at 6 MAP was also positively associated with number of days to shooting and maturity of fruits but negatively associated with fruit bulking period. All the growth, phenology and yield parameters had positive relationship with the leaf-3 $N$ concentration at $6 \mathrm{MAP}$. The number of green leaves at flowering was strongly $(r=$ $0.712 * *)$ related to the leaf-3 $N$ concentration at $6 \mathrm{MAP}$. The $P$ and $\mathrm{K}$ leaf concentrations at 3 MAP were positively correlated with the $N$ and $P$ pulp concentrations. The study showed that the pre-flowering traits, especially the number of green leaves could determine the yield, postharvest qualities and nutrient content of the pulp.
\end{abstract}

Keywords: Plantain, pre-flowering traits, phenology, leaf NPK concentration, yield.

\section{INTRODUCTION}

The vegetative growth qualities of Musa species (bananas and plantains) influence the subsequent yield and postharvest qualities of the plant (Baiyeri et al., 2000a). At the vegetative growth stage, the crop acquires adequate vigour and biomass for eventual distribution to the sink (bunch) during the reproductive stage. Evans (1993) reported that yield is the ultimate outcome of all the processes involved at all stages in the growth and development of a crop, any one of which may limit the yield plateau. In Musa species, the growth and yield relationships had been widely studied (Swennen and De Langhe, 1985; Baiyeri and Mbah, 1997, Baiyeri et al., 2000a). The degree of association among agronomic traits in Musa germplasm was reported to vary with genomic groups (Baiyeri et al., 2000a), different locations and cropping systems (Baiyeri et al., 2000b).

DOI: http://dx.doi.org/10.4314/as.v10i2.9
The identification of those components which contribute to the complex trait, 'yield' is very important (Piepho, 1995) since optimized yield (economic harvest) is the target of every farmer and agricultural researcher. Previous correlation studies between the growth and yield variables in plantains have been based on the growth parameters at flowering and the bunch components. There is scarcity of information on the relationship between the preflowering growth attributes and the bunch yield traits and the pulp nutrient concentrations. The pulp of plantain is the main edible portion of the plant by man and his livestock. Baiyeri and Tenkouano (2008a) suggested that deductions made based on leaf-3 (counting from the topmost unfurled leaf) of Musa spp are reliable for making predictive conclusions in relation to the plant performance. The area and dry weight of leaf-3, respectively had $94 \%$ and $98 \%$ 
predictive precisions for the total leaf area and wholeplant dry matter yield. The aim of this study, therefore, was to determine the relationship between (a) the preflowering growth attributes and bunch yield traits; (b) the pre-flowering leaf-3 nutrient concentrations and pulp nutrient concentration, plant growth and yield parameters; and (c) the growth parameters at flowering and phenology, index of non-spotted leaves (severity of black sigatoka disease infestation), economic and biological yields.

\section{MATERIALS AND METHODS}

The field experiments were conducted at the International Institute of Tropical Agriculture, the high rainfall station at Onne, Rivers State, Nigeria. The experiment lasted for two consecutive cropping cycles (2006 - 2008). The location is a degraded rainforest swamp area characterized by an ultisol derived from coastal sediments with an annual unimodal rainfall of $2400 \mathrm{~mm}$ (Ortiz et al., 1997). The soil has low pH (Table 1) and low cation exchange capacity. Average daily temperature of about $27^{\circ} \mathrm{C}$ and solar radiation averaging $14 \mathrm{MJ} \mathrm{m}^{-2}$ prevail. The location is also associated with high relative humidity with average values ranging from $78 \%$ in February to $89 \%$ in July and September (Ortiz et al., 1997).

Data were collected from two experimental fields laid out as a $3 \times 4$ and $5 \times 2$ factorial experiments, respectively in a randomized complete block design. The effects of two fertilizer sources (organic and inorganic) on four plantain genotypes ('PITA 14', '30456-3', '29525' and 'Agbagba') were studied in the first experiment while in the second experiment, four different times of poultry manure application (at planting, 1, 2 and 3 months after planting) on two plantain genotypes (PITA 17 and French Reversion) were evaluated. No fertilizer application represented the control treatment in both experiments, and the treatment combinations were replicated three times. The plant spacing in each field was $3 \mathrm{~m} \times 2 \mathrm{~m}$, giving a hectare population of 1667 plants.

The cultural practices such as weeding, disease control, propping and pruning were done as recommended by Swennen (1990). The data used to study the relationships between the pre-flowering characteristics (growth and leaf-3 N, P, K concentrations) and the growth attributes at flowering, phenology, bunch yield traits and fruit shelf life were taken from the second experiment while from the first experiment, data for assessing the relationship between growth attributes at flowering and the bunch yield traits were derived.

Pre-flowering data (pseudostem height and circumference, number of green leaves, total leaf area, leaf-3 N, P and $\mathrm{K}$ concentrations) were collected at 3 and 6 months after planting (MAP). The data collected at flowering included number of days to shooting, pseudostem height, pseudostem circumference, number of green leaves (NSLF), youngest spotted leaf (YLSF), and height of the tallest sucker. Bunch yield components, number of days to fruit bulking, number of days to harvest were determined at harvest. The pulp $\mathrm{N}, \mathrm{P}, \mathrm{K}, \mathrm{Ca}, \mathrm{Fe}$ and $\mathrm{Zn}$ concentrations on dry matter bases were also assayed. Fruits were sampled from the second proximal hand per bunch according to Baiyeri and Ortiz (2000) and Caussiol (2001) and used for the ripening test. The index of non-spotted leaves (INSL), harvest index, above-ground biomass were derived as follows; INSL, an index for determining the severity of black sigatoka disease in Musa spp, was calculated at flowering as the ratio of youngest leaf with sigatoka spots (YLSF) to the total number of standing leaves at flowering (NSLF) expressed in percentage (Craenen, 1998).

$\mathrm{INSL}=[(\mathrm{YSLF}-1) / \mathrm{NSLF}] \times 100$

The above-ground biomass was calculated by the summation of the weights of the live leaves, bunch and pseudostem at harvest while the harvest index was calculated as the ratio between the economic yield (bunch weight) and the above-ground biomass. The data were subjected to correlation analysis using the Pearson multiple correlation analysis of SPSS 17.0 (SPSS, 2008) to assess the relationships among all the parameters studied.

\section{RESULTS AND DISCUSSION}

Relationship between pre-flowering growth attributes and growth characteristics at flowering, phenology, bunch yield traits and fruit shelf life at green, fully-ripe and senescence stages:

There was a positive association between the pre-flowering growth attributes and the growth characteristics at flowering (Table 1). The highest correlation coefficient, both at $3 \mathrm{MAP}(0.840 * *)$ and 6 MAP $\left(0.816^{* *}\right)$ was observed between the total leaf area (at 3 and $6 \mathrm{MAP}$ ) and the number of green leaves at flowering. Similarly, the pre-flowering growth traits were significantly correlated with most of the bunch yield and yield components except the number of fruits which did not significantly correlate with the preflowering growth traits. The strongest relationship was observed between the total leaf area both at 3 and 6 MAP and the number of hands. The correlation coefficients were $0.682 *$ and $0.661 *$ respectively, at 3 and 6 MAP. The pseudostem height, circumference and total leaf area at both 3 and 6 MAP were highly negatively related with the number of days to flowering and fruit filling. For instance, the correlation coefficients between the total leaf area and the number of days to flowering and fruit filling, respectively were $-0.919 * *$ and $-0.928 * *$ at $3 \mathrm{MAP}$ while at $6 \mathrm{MAP}$ were $-0.922 * *$ and $-0.931 * *$, respectively. On the other hand, the total leaf area had positive relationship with the number of days to harvest at both 3 and 6 MAP.

The strong relationship between the pre-flowering growth traits, especially the total leaf area (at 3 and 6 MAP) and the growth attributes at flowering, the 
phenology and bunch yield traits revealed that strong relationships exist between the pre-flowering foliar characteristics and growth and yield traits. This is because of the photosynthetic role of the leaves. The leaves via their chlorophyll contents are known for the primary function of converting light energy into photoassimilates; the quantity and amount of photoassimilates produced influence growth and yield performances. The rate of crop growth and development is generally high when the leaf area index is high (Harper, 1983) because the leaves intercept light energy for assimilate production. Photoassimilates produced are eventually distributed to the sink organs, hence Evans (1993) reported the existence of feed-forward effects of source and sink, indicating that the two are interdependent. This means that the sink size will likely increase with increasing source strength. The implication is that with an increase in the function of photosynthetically active leaves (source), more photo-assimilates may be produced for fruit bulking, which will invariably affect the bunch weight and other yield components (Tenkouano et al., 2002).

All the three ripening stages (green, fully-ripe and senescence) of the fruit were positively correlated with most of the pre-flowering growth parameters especially the plant height and the total leaf area (Table $2)$. The total leaf area at 6 MAP had stronger relationship with the fruit green life $\left(\mathrm{r}=0.628^{*}\right)$ and senescence stages $\left(\mathrm{r}=0.789^{*}\right)$ than at $3 \mathrm{MAP}\left(0.621^{* *}\right.$ and $0.731 * *$ for fruit green life and senescence stages, respectively). The strong association that existed between the pre-flowering total leaf area and the fruit shelf life implies that healthy and functional leaves at the early growth stages of plantains will most likely produce healthy fruits that will take longer periods to senesce.

Table 1: Relationship between pre-flowering growth attributes, bunch yield components and henology of plantain

\begin{tabular}{|c|c|c|c|c|c|c|c|c|}
\hline & \multicolumn{4}{|c|}{ 3 MAP } & \multicolumn{4}{|c|}{$6 \mathrm{MAP}$} \\
\hline & $\begin{array}{c}\text { Plant } \\
\text { height } \\
(\mathrm{cm})\end{array}$ & $\begin{array}{c}\text { Pseudostem } \\
\text { circumference } \\
(\mathrm{cm})\end{array}$ & $\begin{array}{l}\text { No. of } \\
\text { green } \\
\text { leaves }\end{array}$ & $\begin{array}{c}\text { Total } \\
\text { leaf area } \\
\left(\mathrm{m}^{2}\right)\end{array}$ & $\begin{array}{l}\text { Plant } \\
\text { height } \\
(\mathrm{cm})\end{array}$ & $\begin{array}{l}\text { Pseudostem } \\
\text { circumference } \\
\text { (cm) }\end{array}$ & $\begin{array}{l}\text { No. of } \\
\text { green leaves }\end{array}$ & $\begin{array}{l}\text { Total } \\
\text { leaf area } \\
\left(\mathrm{m}^{2}\right)\end{array}$ \\
\hline \multicolumn{9}{|c|}{ Growth attributes at flowering } \\
\hline Plant height $(\mathrm{cm})$ & $0.470 * *$ & $0.381^{*}$ & $0.426^{*}$ & $0.635^{* *}$ & $0.388^{*}$ & $0.621 * *$ & 0.096 & $0.597 * *$ \\
\hline $\begin{array}{l}\text { Pseudostem } \\
\text { circumference }(\mathrm{cm})\end{array}$ & 0.308 & 0.217 & 0.349 & $0.444^{*}$ & 0.134 & 0.350 & 0.070 & $0.393 *$ \\
\hline $\begin{array}{l}\text { No. of } \\
\text { green leaves }\end{array}$ & $0.707 * *$ & $0.455^{*}$ & $0.418 * *$ & $0.840^{* *}$ & 0.635 & $0.788^{* *}$ & 0.274 & $0.816^{* *}$ \\
\hline $\begin{array}{l}\text { Index of non-spotted } \\
\text { leaves }\end{array}$ & $0.664 * *$ & $0.514 * *$ & $0.540 * *$ & $0.800^{* *}$ & $0.641 * *$ & $0.757 * *$ & 0.315 & $0.769 * *$ \\
\hline \multicolumn{9}{|c|}{ Bunch yield/yield components } \\
\hline Bunch weight (kg) & 0.324 & 0.228 & $0.396^{*}$ & $0.443 *$ & 0.254 & $0.366^{*}$ & 0.031 & $0.404 *$ \\
\hline No. of hands & $0.571^{* *}$ & $0.450 *$ & $0.445^{*}$ & $0.682 * *$ & $0.466 * *$ & $0.583 * *$ & 0.135 & $0.661 * *$ \\
\hline No. of fruits & 0.179 & 0.216 & 0.082 & 0.212 & 0.054 & 0.110 & 0.125 & 0.125 \\
\hline Fruit length $(\mathrm{cm})$ & $0.491 * *$ & 0.275 & $0.501 * *$ & $0.673 * *$ & $0.422 *$ & $0.601 * *$ & 0.200 & $0.655^{* *} *$ \\
\hline $\begin{array}{l}\text { Fruit circumference } \\
(\mathrm{cm})\end{array}$ & $0.446^{* *}$ & $0.385^{*}$ & $0.385^{*}$ & $0.560 * *$ & $0.441^{*}$ & $0.496 * *$ & 0.063 & $0.550 * *$ \\
\hline Fruit weight $(\mathrm{g})$ & $0.394 *$ & 0.210 & $0.425 *$ & $0.507 * *$ & 0.301 & $0.426 *$ & 0.118 & $0.498 * *$ \\
\hline $\begin{array}{l}\text { Above-ground } \\
\text { biomass }\end{array}$ & $0.441 *$ & 0.293 & $0.437 *$ & $0.578 * *$ & 0.283 & $0.456^{*}$ & 0.006 & $0.488^{* *}$ \\
\hline \multicolumn{9}{|l|}{ Phenology } \\
\hline No. days to shooting & $-0.808 * *$ & $-0.535 * *$ & $-0.382 *$ & $-0.919 * *$ & $-0.785 * *$ & $-0.898 * *$ & $-0.422 *$ & $-0.922 * *$ \\
\hline $\begin{array}{l}\text { No. days to fruit } \\
\text { filling }\end{array}$ & $-0.868 * *$ & $-0.541 * *$ & -0.311 & $-0.928 * *$ & $-0.839 * *$ & $-0.902 * *$ & $-0.431 *$ & $-0.931 * *$ \\
\hline No. days to harvest & 0.328 & 0.338 & $0.491 *$ & $0.547 * *$ & 0.311 & $0.523 * *$ & 0.201 & $0.537 * *$ \\
\hline
\end{tabular}

MAP $=$ Months after planting; $* *$ and $*=$ Correlation is significant at 0.01 and 0.05 , respectively.

Table 2: Relationship between the pre-flowering growth parameters and the fruit shelf life (atgreen, fully- riped and senescence stages) of plantain

\begin{tabular}{|c|c|c|c|c|c|c|c|c|}
\hline \multirow[b]{2}{*}{ Stages } & \multicolumn{4}{|c|}{3 MAP } & \multicolumn{4}{|c|}{6 MAP } \\
\hline & $\begin{array}{c}\text { Plant height } \\
(\mathrm{cm})\end{array}$ & $\begin{array}{c}\text { Pseudostem } \\
\text { circumference } \\
(\mathrm{cm})\end{array}$ & $\begin{array}{l}\text { No. of } \\
\text { green } \\
\text { leaves }\end{array}$ & $\begin{array}{l}\text { Total leaf } \\
\text { area }\left(\mathrm{m}^{2}\right)\end{array}$ & $\begin{array}{c}\text { Plant height } \\
(\mathrm{cm})\end{array}$ & $\begin{array}{c}\text { Pseudostem } \\
\text { circumference } \\
(\mathrm{cm})\end{array}$ & $\begin{array}{l}\text { No. of } \\
\text { green } \\
\text { leaves }\end{array}$ & $\begin{array}{l}\text { Total leaf } \\
\text { area }\left(\mathrm{m}^{2}\right)\end{array}$ \\
\hline Green life & $0.539 * *$ & 0.263 & 0.245 & $0.621 * *$ & $0.475 * *$ & $0.557 * *$ & $0.450 *$ & $0.628 * *$ \\
\hline Fully riped & $0.558 * *$ & 0.299 & 0.292 & $0.507 * *$ & $0.409^{*}$ & $0.369^{*}$ & 0.229 & $0.455 * *$ \\
\hline Senescence & $0.637 * *$ & $0.427^{*}$ & 0.320 & $0.731 * *$ & $0.681 * *$ & $0.735^{* *}$ & 0.277 & $0.789 * *$ \\
\hline
\end{tabular}

MAP $=$ Months after planting; $* *$ and $*=$ Correlation is significant at 0.01 and 0.05 , respectively. 


\section{Relationship between growth parameters at flowering and bunch yield traits:}

All the bunch yield traits (bunch weight, number of hands and fruits) and fruit metric traits (fruit weight, fruit length, fruit circumference) were related to the growth parameters at flowering (Table 3). The growth parameters most strongly related to the bunch and fruit traits varied across the four genotypes. The pseudostem height and circumference were frequently and highly associated with the bunch and fruits traits especially in the tetraploid hybrids, 'PITA 14' and '29525'. The highest correlation coefficients between the growth traits at flowering and yield traits were always observed in 'PITA 14'. For instance, the correlation coefficient between the plant stature (pseudostem height and circumference) and the number of hands were $0.969 * *$ and $0.982^{* *}$, respectively in 'PITA 14'.

The coefficient of determination between the bunch yield traits and the plant stature (pseudostem height and circumference) was generally high, greater than $80 \%$ in some cases in 'PITA 14'. The correlation coefficients between the pseudostem height and circumference and number of hands, number of fruits, fruit weight, fruit length, fruit circumference and bunch weight were $0.969^{* *}$ and $0.982^{* *}, 0.940^{* *}$ and $0.965^{* *}, 0.925^{* *}$ and $0.919^{* *}, 0.955^{* *}$ and $0.934 * *$ $0.703^{*}$ and $0.720^{*}, 0.877^{* *}$ and $0.900^{* *}$, respectively. The number of green leaves at flowering also showed strong relationships with the bunch and fruit traits in 'PITA 14' and '30456-3'. However, in the landrace, 'Agbagba' there were very poor relationship between the bunch yield traits and number of live leaves at flowering, but the relationship was fairly strong with the pseudostem height and circumference.

The strong relationship between the bunch yield traits and the plant stature (pseudostem height and circumference) at flowering corroborates the finding of Baiyeri et al. (2008b). This suggested that the increase in the biomass production during the vegetative stage of the plant could increase the bunch yield, implying that crop management strategies that will improve the plant's biomass before flowering may eventually translate into heavy bunch harvest (Baiyeri et al., 2008). Musa crops with heavy bunches will require correspondingly large plant stature (pseudostem height and circumference) to avoid snapping or toppling of the pseudostem.

Relationship between the growth parameters at flowering and the harvest index and aboveground biomass, phenology and index of non-spotted leaves of plantain:

The harvest index and all the vegetative traits at flowering had relatively high significant correlation in all the tetraploid hybrids (Table 4). The harvest index was highly correlated with the number of green leaves at flowering in 'PITA 14' and '30456-3' compared to the other growth attributes. For instance,
'PITA 14' had a correlation coefficient of $0.952 * *$ for number of green leaves as related to the harvest index. This could be because, at flowering (shooting of the bunch), which is the commencement of the reproductive stage, the bunch becomes the major sink, where heavy demands of photo-assimilates are made for proper bulking of the fruits. Therefore, the more the number of green leaves (photosynthetic active leaves) at this stage, the higher the conversion of light energy to dry matter, and this may eventually be translocated to the bunch for higher economic yield.

The plant height and pseudostem circumference at flowering were significantly associated with the above-ground biomass at harvest in all the genotypes (Table 4). The number of green leaves at flowering however had relatively weak association with the above-ground biomass in most of the genotypes. This may be due to the fact that plantain, being a fruit plant, usually accumulates a lot of biomass in terms of height and stem girth thereby constituting a great proportion of the above-ground biomass. Secondly, plantains are determinate plants; some of the leaves produced during the vegetative growth stage get dried up, majorly as a result of transportation of photo-assimilates from the leaves to the bunch (sink) during the reproductive stage, hence leaving behind few leaves at harvest which contribute a small proportion of the above-ground biomass. This further explains why the above-ground biomass at harvest was more related to the plant stature than the number of green leaves at flowering.

There was a high variability in the correlation coefficients between the vegetative parameters at flowering and the phenology and black sigatoka disease parameters (Table 4). In all the genotypes, there was significant and positive relationship between the plant stature (pseudostem height and circumference) and the number of days to shooting, fruit bulking and harvest. The most related phenological traits with the vegetative parameters in all the genotypes were the number of days to shooting and harvest. The relationship was strongest in the hybrids, 'PITA 14' and '29525', having correlation coefficients of $0.967 * *, \quad 0.913^{* *}$, and $0.987 * *, 0.930^{* *}$, respectively for number of days to shooting and harvest. The significant and positive correlations between the plant stature at flowering and the phenology agreed with the work of Swennen et al. (1995), who reported that taller plantains flowered later than plantains with intermediate height and this in turn flowered later than dwarf plantains. The implication is that any factor, such as nitrogen fertilization that promotes luxuriant growth of the plant may eventually prolong the shooting period and consequently longer days to harvesting of the bunch. However, taller plants (of the same genotype) produce bigger bunches.

The vegetative attributes at flowering, generally were strongly related to the index of nonspotted leaves (parameter for black sigatoka disease 
assessment) especially the number of green leaves that had positive and strongest association with the index of non-spotted leaves in all the genotypes. The correlation coefficients were $0.957 * *, 0.823 * *, 0.803 * *$ and 0.493* in 'PITA 14', '30456-3', 'Agbagba' and ' 29525 ', respectively for the number of green leaves and the index of non-spotted leaves. The number of green leaves (at flowering) and the youngest leaf with sigatoka spots are the black sigatoka disease response parameters used in determining the index of nonspotted leaves. The higher the value of the index of non-spotted leaves, the healthier the leaves. Higher the number of standing (green) leaves and less leaf area with black sigatoka spots, the lower the black sigatoka severity on plantain (Mobambo et al., 1994). Severe cases of black sigatoka symptom may induce yield loss (up to 33-50\% in West Africa) through a reduction of fruit per bunch and lower fruit weight by the defoliation of leaves and decreased functional leaf area (Mobambo et al., 1993). Therefore, any agronomic practice that will increase the number of green leaves and reduce the infection of the fungal spores on the leaves especially before flowering will definitely enhance the yield of plantain

Table 3: Relationship between the growth parameters at flowering and bunch yield traits of plantain.

\begin{tabular}{|c|c|c|c|c|}
\hline Yield/yield components & Genotype & $\begin{array}{l}\text { Plant height } \\
\text { (cm) }\end{array}$ & $\begin{array}{c}\text { Pseudostem } \\
\text { circumference } \\
(\mathrm{cm})\end{array}$ & $\begin{array}{c}\text { No. of } \\
\text { green leaves }\end{array}$ \\
\hline \multirow[t]{4}{*}{ Bunch weight (kg) } & 'PITA 14' & $0.877 * *$ & $0.900 * *$ & $0.549^{*}$ \\
\hline & '30456-3' & $0.620 * *$ & $0.730^{* *}$ & $0.686^{* *}$ \\
\hline & 'Agbagba' & $0.603 * *$ & $0.504^{* *}$ & 0.253 \\
\hline & '29525’' & $0.872 * *$ & $0.838^{* *}$ & 0.052 \\
\hline \multirow[t]{4}{*}{ Number of hands } & 'PITA 14' & $0.969 * *$ & $0.982 * *$ & $0.827 * *$ \\
\hline & '30456-3’' & $0.633 * *$ & $0.720 * *$ & $0.727 * *$ \\
\hline & 'Agbagba' & $0.486^{*}$ & 0.191 & 0.250 \\
\hline & '29525’ & $0.540^{*}$ & $0.559 *$ & 0.165 \\
\hline \multirow[t]{4}{*}{ Number of fruits } & 'PITA 14' & $0.940^{* *}$ & $0.965^{* *}$ & $0.712 * *$ \\
\hline & '30456-3’' & $0.650 * *$ & $0.730 * *$ & $0.677 * *$ \\
\hline & 'Agbagba' & 0.268 & 0.099 & 0.213 \\
\hline & '29525’' & $0.728 * *$ & $0.725^{* *}$ & 0.060 \\
\hline \multirow[t]{4}{*}{ Fruit length $(\mathrm{cm})$} & 'PITA 14' & $0.955^{* *}$ & $0.934 * *$ & $0.853^{* *}$ \\
\hline & '30456-3’' & $0.612 * *$ & $0.708^{* *}$ & $0.762 * *$ \\
\hline & 'Agbagba' & $0.545^{*}$ & $0.638^{* *}$ & 0.195 \\
\hline & ' $29525 ’$ & $0.785^{* *}$ & $0.743^{* *}$ & 0.053 \\
\hline \multirow[t]{4}{*}{ Fruit circumference $(\mathrm{cm})$} & PITA 14' & $0.703 * *$ & $0.720 * *$ & $0.552 *$ \\
\hline & '30456-3’' & $0.631 * *$ & $0.720 * *$ & $0.734 * *$ \\
\hline & 'Agbagba' & $0.789^{* *}$ & $0.744^{*} *$ & 0.148 \\
\hline & '29525' & $0.789^{* *}$ & $0.752^{* *}$ & 0.061 \\
\hline \multirow[t]{4}{*}{ Fruit weight (g) } & 'PITA 14' & $0.925 * *$ & $0.919^{* *}$ & $0.715^{* *}$ \\
\hline & '30456-3’' & $0.601 * *$ & $0.714^{* *}$ & $0.762 * *$ \\
\hline & 'Agbagba' & $0.743^{* *}$ & $0.709^{* *}$ & 0.151 \\
\hline & '29525' & $0.832 * *$ & $0.812^{* *} *$ & -0.049 \\
\hline
\end{tabular}

\footnotetext{
$* *$ and $*=$ Correlation is significant at 0.01 and 0.05 , respectively.
} 
Table 4: Relationship between the growth parameters at flowering and harvest index, aboveground biomass, phenology and index of non-spotted leaves of plantain.

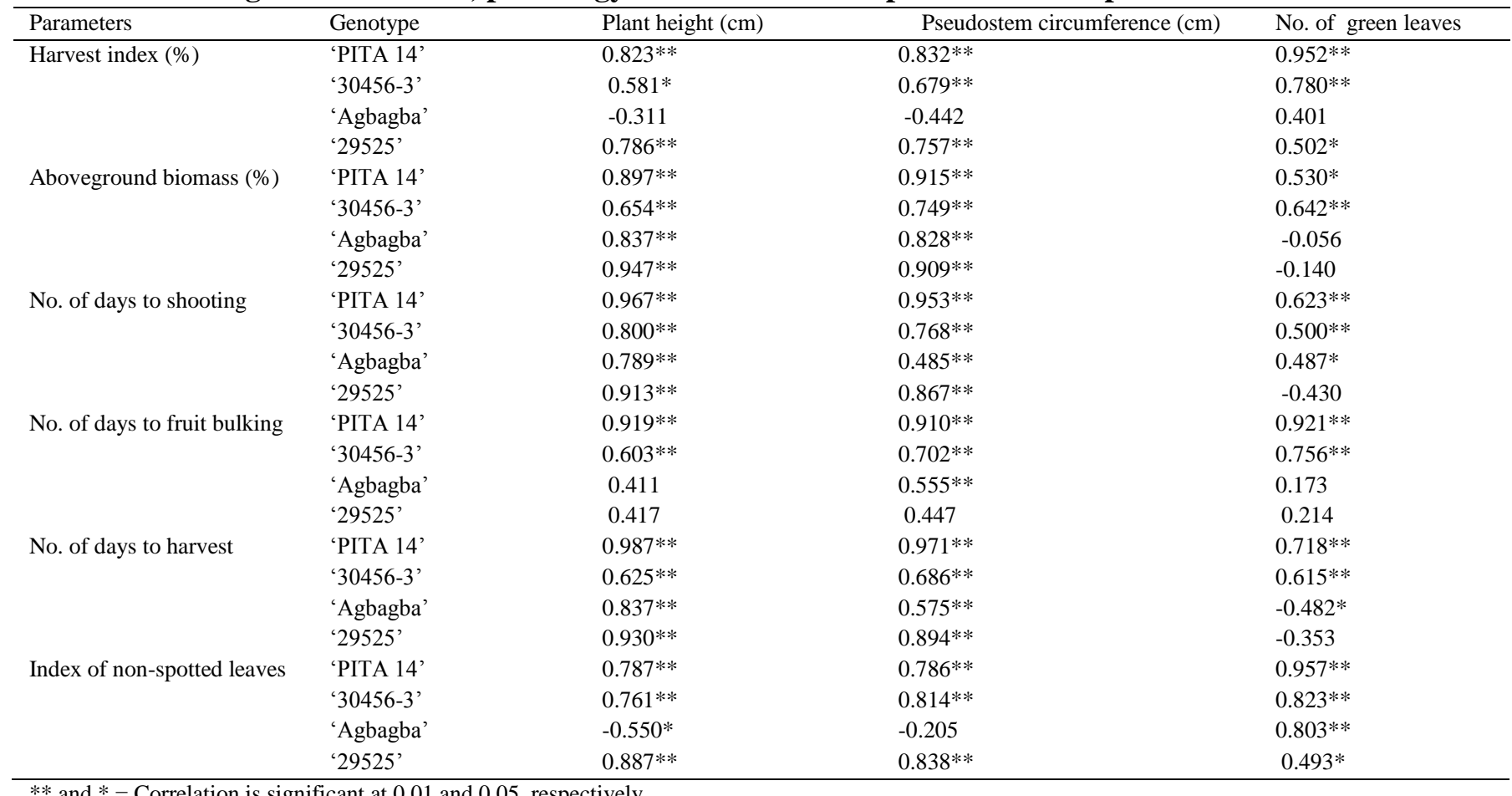

Table 5: Relationship between leaf-3 NPK concentrations at 3 and 6 MAP and some growth traits at flowering, phenology and bunch yield traits.

\begin{tabular}{|c|c|c|c|c|c|c|}
\hline & \multicolumn{3}{|c|}{3 MAP } & \multicolumn{3}{|c|}{6 MAP } \\
\hline & $\mathrm{N}(\%)$ & $\mathrm{P}(\%)$ & $\mathrm{K}(\%)$ & $\mathrm{N}(\%)$ & $\mathrm{P}(\%)$ & $\mathrm{K}(\%)$ \\
\hline \multicolumn{7}{|l|}{ Growth traits at flowering } \\
\hline Plant height $(\mathrm{cm})$ & $0.497 * *$ & $0.512 * *$ & $0.538^{* *}$ & $0.568 * *$ & -0.094 & -0.145 \\
\hline Pseudostem circumference $(\mathrm{cm})$ & 0.316 & $0.560 * *$ & $0.455^{* * *}$ & $0.503 * *$ & -0.060 & -0.055 \\
\hline No. of green leaves & -0.185 & $0.632 * *$ & $0.621 * *$ & $0.712 * *$ & -0.150 & 0.248 \\
\hline \multicolumn{7}{|l|}{ Phenology } \\
\hline No. days to shooting & 0.181 & $-0.536 * *$ & $-0.653 * *$ & $0.613^{* *}$ & 0.052 & -0.255 \\
\hline No. days to fruit filling & -0.239 & $0.750 * *$ & $0.685^{* * *}$ & $-0.534 * *$ & 0.193 & $0.410^{*}$ \\
\hline No. days to harvest & 0.131 & $-0.425 *$ & $-0.568 * *$ & $0.583 * *$ & 0.145 & -0.187 \\
\hline \multicolumn{7}{|l|}{ Yield and yield components } \\
\hline Bunch weight (kg) & $0.395^{*}$ & $0.413^{*}$ & $0.398 * *$ & $0.476^{* *}$ & -0.116 & -0.155 \\
\hline No. of hands & 0.193 & $0.600^{* * *}$ & $0.547 * *$ & $0.564 * *$ & -0.071 & -0.033 \\
\hline No. of fruits & 0.173 & 0.188 & 0.061 & 0.060 & 0.112 & -0.169 \\
\hline Fruit length $(\mathrm{cm})$ & $0.389 *$ & $0.680^{* * *}$ & $0.626^{* * *}$ & $0.657 * *$ & -0.169 & -0.312 \\
\hline Fruit circumference $(\mathrm{cm})$ & 0.230 & $0.450^{*}$ & $0.470 * *$ & $0.510^{* *}$ & -0.041 & -0.162 \\
\hline Fruit weight $(\mathrm{g})$ & 0.294 & $0.621 * *$ & $0.463 * *$ & $0.614 * *$ & -0.130 & -0.208 \\
\hline
\end{tabular}

MAP $=$ Months after planting; $* *$ and $*=$ Correlation is significant at 0.01 and 0.05 , respectively. 
Table 6: Relationship between NPK concentrations of leaf-3 at 3 and 6 MAP and pulp nutrient concentrations of plantain.

\begin{tabular}{|c|c|c|c|c|c|c|c|}
\hline \multirow[b]{2}{*}{ Month after planting } & \multirow[b]{2}{*}{$\begin{array}{l}\text { Leaf nutrient } \\
\text { contents }(\%)\end{array}$} & \multicolumn{6}{|c|}{ Pulp nutrient concentration (\%) } \\
\hline & & $\mathrm{N}$ & $\mathrm{P}$ & $\mathrm{K}$ & $\mathrm{Ca}$ & $\mathrm{Fe}$ & $\mathrm{Zn}$ \\
\hline \multirow[t]{3}{*}{3} & $\mathrm{~N}$ & -0.184 & $-0.394 *$ & $-0.430 *$ & -0.308 & -0.086 & -0.266 \\
\hline & $\mathrm{P}$ & $0.530 * *$ & $0.524 * *$ & 0.234 & 0.111 & 0.120 & 0.077 \\
\hline & $\mathrm{K}$ & $0.630 * *$ & $0.583 * *$ & 0.346 & 0.336 & 0.012 & 0.151 \\
\hline \multirow[t]{3}{*}{6} & $\mathrm{~N}$ & $-0.398 *$ & $-0.467 * *$ & -0.350 & -0.130 & 0.028 & -0.048 \\
\hline & $\mathrm{P}$ & 0.081 & 0.299 & -0.007 & 0.213 & 0.215 & 0.246 \\
\hline & $\mathrm{K}$ & 0.206 & 0.182 & -0.003 & 0.185 & -0.136 & 0.049 \\
\hline
\end{tabular}

MAP $=$ Months after planting; $* *$ and $*=$ Correlation is significant at 0.01 and 0.05 , respectively.

Relationship between leaf-3 NPK concentrations at 3 and 6 MAP and growth traits at flowering, phenology and bunch yield traits: At 3 MAP, the leaf-3 $N$ concentration had positive but weak correlation with the plant height at flowering, bunch weight and fruit length (Table 5). The concentration of $\mathrm{P}$ and $\mathrm{K}$ in the leaves at $3 \mathrm{MAP}$, however, had a positive association with the number of green leaves at flowering, fruit bulking period and the entire yield attributes. Bunch weight, number of hands and fruit quality are determined by potassium (Murray, 1960). Potassium improves water use efficiency through osmotic regulation of plant stomata by modulating transpiration of water and the penetration of atmospheric carbon dioxide into the leaf (IPI, 2006). Phosphorus has been reported to cause increase in plantain nutrient uptake, leaf photosynthesis (Kozi et al., 1992) and improves water relations and chlorophyll content (Williams, 1993). The result suggested that the supply of adequate $\mathrm{P}$ and $\mathrm{K}$ at the earlier vegetative stage may eventually culminate to high bunch yield.

However, in terms of the phenology, the leaf-3 $\mathrm{N}$ concentration at 6 MAP was also positively associated with the number of days to shooting and maturity of fruits but negatively associated with fruit bulking period (Table 5). The higher $\mathrm{N}$ accumulation at this stage (6 MAP) may induce luxuriant growth and longer vegetative period, at the expense of flowering and the consequent development (bulking) of bunch. The leaf-3 P concentration at 6 MAP did not show any relationship with the growth traits at flowering, phenological and bunch yield traits. The number of days to fruit filling was the only attribute among the growth traits, phenology and bunch yield traits that was associated with the leaf- $3 \mathrm{~K}$ concentration at 6 MAP. The relationship was positive but weak $\left(0.410^{*}\right)$.

Most of the growth, phenology and yield parameters had positive relationship with the leaf-3 $\mathrm{N}$ concentration at $6 \mathrm{MAP}$. The number of green leaves at flowering had the strongest relationship $(\mathrm{r}=0.712 * *)$ with the leaf- $3 \mathrm{~N}$ concentration which was followed by the fruit length $(\mathrm{r}=0.657 * *)$ and fruit weight $(\mathrm{r}=$ $\left.0.614^{* *}\right)$. The increase in leaf- $\mathrm{N}$ concentration at the pre-flowering stage could have enhanced the vigorous and luxuriant vegetative growth, since there is a close relationship existing between dry matter accumulation and plantain leaf nitrogen level (Robinson, 1996). This luxuriant growth may have delayed flowering and fruit maturation as there was a positive relationship between the leaf- $3 \mathrm{~N}$ concentration and phenology.

Relationship between NPK concentrations in leaf-3 at 3 and 6 MAP and pulp nutrient concentrations of plantain: The relationship between the pulp N, P and $\mathrm{K}$ concentrations and the leaf-3 $\mathrm{N}$ concentration, both at 3 and 6 MAP, were significantly negative (Table 6). This implied that excessive supply of nitrogen at the pre-flowering stage of plantain could induce luxuriant growth of the plants to the detriment of the bunch quality (in terms of the nutrient concentrations of the fruits). The $\mathrm{P}$ and $\mathrm{K}$ leaf concentrations at 3 and 6 MAP were positively correlated with the $\mathrm{N}$ and $\mathrm{P}$ pulp concentrations, suggesting that higher concentrations of $\mathrm{N}$ and $\mathrm{P}$ in the pulp could be achieved by increased accumulation of $\mathrm{P}$ and $\mathrm{K}$ by the leaf at the vegetative growth stage. The uptake of $\mathrm{P}$ by the roots of plantain has been reported to cause increased plantain nutrient uptakes (Robson and Pitman, 1983). The uptake of P is apparently enhanced by the association of roots with vesicular-arbuscular mycorrhizae (Fox, 1989) which increases the surface of the root for the absorption of other nutrients. Similarly, the uptake of $\mathrm{K}$ is greater during the first half of the vegetative growth phase than during bunch development. Low $\mathrm{K}$ supply in the soil adversely affects translocation and utilization of all other mineral nutrients (Robinson, 1996). The implication, therefore, is that increased $\mathrm{K}$ supply at the early stage of plantain growth could enhance increased absorption and utilization of the other nutrients, especially towards the development of the quality fruits. 


\section{CONCLUSION}

The study showed that the pre-flowering growth traits especially the foliar characteristics of plantain crop could greatly influence the fruiting, yield and the quality of plantain fruits (in terms of NPK concentrations). At the pre-flowering stage, the plant through the functional green leaves may accumulate adequate biomass for shooting, physiological features for bunch support against toppling as well as adequate photo-assimilates for higher dry matter accumulation and distribution to the economic part (bunch and fruits) of plantain. When good and adequate crop management practices are employed at the early growth stage of plantains (to ensure functional and high photosynthetically active leaves), a higher bunch yield and fruit dry matter could be produced eventually.

\section{REFERENCES}

Baiyeri, K. P. and Tenkouano, A. (2008a). Manure placement effects on root and shoot growth and nutrient uptake of 'PITA 14' Plantain hybrid (Musa sp. AAAB). African Journal of Agricultural Research, 3 (1): 13-21.

Baiyeri, K. P. and Tenkouano, A. (2008b). Variability in agricultural and biological yields of ten Musa genotypes evaluated for two cropping cycles in a sub-humid environment of Nigeria. Journal of Crop Improvement (USA) 21(1): 27-40.

Baiyeri, K. P. and Mbah, B. N. (1997). Functional relationships among growth and yield components of falsehorn plantains (Musa spp. AAB). Proceedings, 15th HORTSON Conference, NIHORT Ibadan, 7th-11 th April, 1997.

Baiyeri, K. P. and Ortiz, R. (2002). Agronomic evaluation of plantain and other triploid Musa. In: K. Craenen, R. Ortiz, E. B. Karamura and D. R. Vuylsteke (eds.). Proceeding of First International Conference of Banana and Plantain in Africa, Kampala, Uganda, 12-18 October, 1996. International Society for Horticulturae, 540: 125-135.

Baiyeri, K. P., Mbah, B. N. and Tenkouano, A. (2000a). Relationship between phenological and yield traits of the plant crop and first ratoon crop of Musa genotypes as affected by ploidy level and genomic group. AgroScience 1(1): 113121.

Baiyeri, K. P., Tenkouano, A., Mbah, B. N. and Mbagwu, J. S. C. (2000b). Ploidy and genomic group effects on yield components interactions in bananas and plantains across four environments in Nigeria. Scientia Horticulturae, 85: 51-62.

Caussiol, L. (2001). Postharvest quality of conventional and organically grown banana fruit. M.Sc thesis submitted to Cranfield University at Silsoe. 148 pp.
Craenen, K. (1998). Black Sigatoka disease of banana and plantain: a reference manual. International Institute of Tropical Agriculture, Ibadan, Nigeria. 60pp.

Evans, L.T. (1993). Crop evolution, adaptation and yield. Cambridge University Press. 500p.

Fox, R. L. (1989). Detecting mineral deficiencies in tropical and temperate crops. In: Plucknett, D. L. and Sprague, H. E. (eds.). Westview Tropical Series 7. Westview Press, boulder, CO, USA.

Harper, F. (1983). Principles of crop production. Granada Publishing Ltd., United Kingdom. p. 51.

IPI (2006). Potassium in plant production. International Potash Institute. http://www.ipipotash.org/slides/kipp2.html.

Jones, B., Wolf, H. and Mills, A. (1991). Plant Analysis Handbook. Micro-Macro Publishing, Inc., Athens, USA

Kozi, T., Fujiwara, K. and Hayashi, M. (1992). Environmental control in micropropagation. Department of Horticulture, Chiba University, Matsudo, Chiba 271, Japan, pp. 47-143.

Mobambo, K. N., Gauhl, F. and Pasberg-Gauhl, C. (1993). Plantain response to black sigatoka in backyard gardens and fields in south-eastern Nigeria. MusAfrica 3: 3-4.

Mobambo, K. N., Zuofa, K., Gauhl, C., Adeniji, M. O. and Pasberg-Gauhl, C. (1994). Effect of soil fertility on host response to black leaf streak of plantain (Musa spp., AAB group) under traditional farming systems in southeastern Nigeria. International Journal of Pest Management, 40 (1): 75-80.

Murray, D. E. (1960). The effect of deficiencies of the major nutrients on growth and leaf analysis of the banana. Tropical Agriculture, 37: 97-106.

Ortiz, R., Austin, P. D. and Vuylsteke, D. (1997). IITA high rainfall station: Twenty years of research for sustainable agriculture in the West African humid forest. Hortscience, 32 (6): 969-972.

Piepho, H. P. (1995). A simple procedure for yield component analysis. Euphytica. 84: 43-48.

Robinson, J. C. (1996). Bananas and Plantains. United Kingdom: CAB International. $142 \mathrm{pp}$.

Robson, A. D. and Pitman, M. G. (1983). Interactions between nutrients in higher plants, pp. 147180. In: A. Lauchli and R. L. Bieleski (eds.), Inorganic Plant Nutrition. In: A. Pirson and $\mathrm{M}$. H. Zimmermann (eds.), Encyclopaedia of Plant Physiology, New Series, Vol. 15A. SpringerVerlag, New York, NY.

SPPS (2008). SPSS Statistics 17.0 for Windows Evaluation Version, Release 17.0.0. SPSS Inc.

Swennen, R. (1990). Plantain Cultivation under West African Conditions: A Reference Manual. IITA, Ibadan, Nigeria. 24pp. 
Ndukwe, O. O. , Baiyeri, K. P., Muoneke, C. O. and Tenkouano, A.

Swennen, R. and De Langhe, E. (1985). Growth Parameters of Yield of Plantain (Musa cv. AAB). Annals of Botany. 56: 197-204.

Swennen, R., Vuylsteke, D. and Ortiz, R. (1995). Phenotypic diversity and pattern of variation in west and central African plantains (Musa spp., AAB group Musaceae). Economic Botany. 49(3):3 20-327.

Tenkouano, A., Ortiz, R. and Baiyeri, K. P. (2002). Phenotypic and genetic correlation in Musa populations in Nigeria. African Crop Science Journal. 10(2): 121-132.

Williams, R. R. (1993). Mineral nutrition in vitro. A mechanistic approach. Australian Journal of Botany, 41: 237-251. 